\title{
Leaching of carbon from native and non-native leaf litter of subtropical riparian forests
}

\author{
Daniel J. DA SILVA, ${ }^{1}$ Alice T. VALDUGA,,${ }^{1}$ Joseline MOLOZZI,,${ }^{2}$ Rodrigo FORNEL,${ }^{1}$ Rozane M. RESTELLO, \\ Luiz U. HEPP ${ }^{*}$
}

${ }^{1}$ Programa de Pós-Graduação em Ecologia, Universidade Regional Integrada do Alto Uruguai e das Missões, Av. Sete de Setembro 1621, Erechim, RS, 99709-910; ${ }^{2}$ Programa de Pós-Graduação em Ecologia e Conservação, Universidade Estadual da Paraíba, Campina Grande, PB, 58429-500, Brazil

*Corresponding author: luizuhepp@gmail.com

\begin{abstract}
We evaluated the leaching of dissolved organic and inorganic carbon (DOC and DIC, respectively) from leaf litter of plant species of the native Atlantic Forest and of Pinus elliottii (Engelm.) and Eucalyptus grandis (Hill ex Maiden) forests. We carried out experiments in which leaves from each forest system (native, E. grandis, and $P$. elliottii) were placed in reactors with sterile water. After $1 / 4 \mathrm{~h}, 1 \mathrm{~h}, 4 \mathrm{~h}, 12 \mathrm{~h}, 24 \mathrm{~h}$, and $48 \mathrm{~h}$ of incubation, we quantified the concentrations of DIC and DOC of each leachate. The greatest quantity of DIC was leached in the native forest system, whereas the greatest quantity of DOC was leached in the $E$. grandis forest system. With respect to the period of year, the greatest quantity of DIC was leached in autumn, whereas that of DOC was leached in the summer. Our results demonstrated that the replacement of native species in riparian zones, by non-native forest monocultures, could alter the chemical composition of the water. Finally, the results presented in this paper reinforce the need for a more careful look at ecological processes.
\end{abstract}

Key words: Atlantic forest; Eucalyptus grandis; litter decomposition; Pinus elliottii; riparian zone; stream ecology.

Received: May 2017. Accepted: January 2018.

\section{INTRODUCTION}

Forest systems play a key role in the sequestration of atmospheric carbon and are the main regulators of carbon dynamics in ecosystems. Carbon in aquatic ecosystems is mainly derived from processes that occur in terrestrial ecosystems (Finlay, 2003). The organic matter that sustains the dissolved carbon flux from terrestrial aquatic ecosystems can originate from processes that occur in soil, riparian vegetation, and landscape (Dahn, 1981; Hillman et al., 2004; Wilson and Xenopoulos, 2008). In addition, the importance of aquatic environments in the terrestrial carbon cycle has been increasing, since there is a global flow between terrestrial-aquatic environments of about 1.9 Pg C year ${ }^{-1}$ (Öquist et al., 2009). The flux of organic matter from terrestrial to aquatic environments occurs mainly vertically or lateral way (Bampi et al., 2017; Tonin et al., 2017). In addition, biotic (e.g. phenology; Capellesso et al., 2016) and abiotic factors (e.g. precipitation; Tonin et al., 2017) contribute decisively to input of allochthonous organic matter into aquatic environments.

The riparian forests, composed of native vegetation, have greater biodiversity and, consequently, accumulate more carbon in their biomass (Allan and Castillo, 2007; Rezende et al., 2008). Furthermore, it is important to note that there is a correlation between the number of tree species and the amount of organic matter in the soil (Buonocore et al., 2014; Corral-Fernández et al., 2013). The plant species with varied chemical composition compose a litter that can chemically influence the soil, since the leaves can leach different chemical compounds (Duan et al., 2014; Capellesso et al., 2016). Besides that, the leaf litter can leach different chemical compounds in different quantities and periods of the year (Duan et al., 2014). These chemical variabilities alter the structure and dynamics of nutrient cycling, especially that of carbon (Canhoto and Laranjeira, 2007; Huang et al., 2013).

The organic matter input to the small-order streams ensures the supply of matter and energy to these environments inducing changes in communities and food webs (Wallace et al., 1997; Kominoski and Rosemond, 2012). In this region, the canopy is responsible for covering more than $80 \%$ of the stream (Bambi et al., 2012) and shading makes primary production impossible, making riparian vegetation allochthonous the main source of energy for streams (Vanotte et al., 1980). Thus, allochthonous organic matter is important to trophic webs of these streams depend on the riparian vegetation for obtaining nutrients, which is fundamental for the aquatic communities (Naimann and Décamps, 1990; Richardson and Sato, 2015; Schulz et al., 2015). The organic matter 
that enters the streams is composed of leaves, branches, needles, bark, fruits, seeds, and other plant components (Lamberti and Gregory, 2007; Gonçalves and Callisto, 2013). Once in the stream, coarse particulate organic matter undergoes numerous physical, chemical, and biological transformation processes until it is converted into fine particulate organic matter and dissolved material (Graça, 2001).

Leaching is the abiotic removal of water-soluble constituents from litter plant (Moorhead et al., 1996; Bärlocher, 2005). The leaching of the soluble compounds occurs rapidly in the stream, which may last a few hours and days (Duan et al., 2014). The release of soluble compounds is important for aquatic ecosystems, since senescent biomass is in permanent contact with water (Polunin, 1984). As such, water-soluble substances are rapidly incorporated into dissolved organic matter (DOM), increasing the potential for use by microbial metabolism (Wetzel, 1995). The decomposition of the DOM results in dissolved inorganic carbon (DIC) and dissolved organic carbon (DOC) that is recognised as a major component in the global carbon cycle (Yamashita et al., 2011).

The DIC is related to $\mathrm{CO}_{2}$ production in the soil, microbial respiration and by plant roots (Finlay, 2003). In addition, there is a relationship with the atmospheric $\mathrm{CO}_{2}$ flow (Cole et al., 1994), attributing a biogeochemical importance to this chemical element and ecosystems. On the other hand, DOC, which constitutes mainly humic substances resulting from chemical decomposition, is chemically heterogeneous and has a high molecular weight (Mcknight and Aiken, 1998; Lennon and Pfaff, 2005).

The chemical composition of leaves, especially the concentration of carbon, may be the main factor regarding the leaching of DIC and DOC from the leaf litter of different forest systems. On one hand, leaves are composed of carbohydrates, which are produced during photosynthesis, that provide material for the biosynthesis of all organic molecules that are mainly in cellulose (Cunha-Santino et al., 2003). Polyphenols are important cellular support materials and form the structure of cell walls (Strak, 1997). Thus, one of the ways to better understand the processing of organic matter in aquatic environments is to study the different steps of the process under controlled conditions (i.e., in the laboratory). The evaluation of leaching in a controlled experiment with debris produced by different forest systems (e.g., native and non-native) can provide information on carbon dynamics in aquatic environments.

The practice of replacing native species in riparian areas has become problematic on a global scale (Giling et al., 2014). It is estimated that reforestation occupies 264 million hectares worldwide. In Brazil, the amount of cultivated area has continuously increase, reaching 7.7 million hectares, while the amount of native areas has decreased by 40 million hectares since the year 2000 (Oliveira, 2015). Of these cultivated areas, a majority of non-native species are either Eucalyptus or Pinus. This anthropogenic activities may affect aquatic ecosystems by altering water characteristics, main the concentrations of dissolved organic matter, nutrients, and other elements (Hillman et al., 2004). Thus, changes in vegetation structure in riparian areas of small streams affect supplies of allochthonous organic matter (e.g., DOC and DIC) that contribute as an energy source to the aquatic biota.

However, the knowledge about the relationships between riparian zones and the concentrations of DIC and DOC leached from native or non-native allochthonous organic matter is incipient. Thus, our main motivation was to elucidate aspects related to ecological processes helps in understanding the mechanisms of inventory and carbon flows in riparian systems. In this study, we evaluated the leaching of DIC and DOC of leaf litter from native plant species of the Atlantic Forest and non-native forestry of Pinus elliottii (Engelm.) and Eucalyptus grandis (Hill ex Maiden). Our hypothesis is that the native leaf litter will leach higher amounts of DIC, because it is a mix of plant species from the riparian zone of streams. Further, we expect that DOC leaching will be higher in E. grandis because it is a species with a large amount of watersoluble compounds (e.g., phenols). Finally, we believe that the leaching depends on the season of the year, because the chemical characteristics of the leaves vary annually according to their senescence. Therefore, with an experimental approach, we try to understand how the leaching dynamics of DOC and DIC from native and nonnative litter plant occur. Finally, we seek to generate information that contributes to the understanding of the processes that involve the carbon cycle in streams and the impacts of the native substitution by non-native species.

\section{METHODS}

\section{Sampling site}

We performed an ex situ study using leaves collected in riparian zones of streams located in the extreme southern portion of Brazil. The landscape of the region is fragmented, with a predominance of agricultural activities (approximately 70\%) and forest remnants in the secondary stage. The climate type (c.f. Köppen) is Cfa (temperate subtropical), with an average annual temperature of $18^{\circ} \mathrm{C}$, an average annual rainfall of 1800 $\mathrm{mm}$ (Alvares et al., 2013), and an average altitude of 734 $\mathrm{m}$ above sea level. The vegetation is characterised as a transition between Semideciduous Atlantic Forest and Atlantic Forest with Araucaria angustifolia (Bertol. Kuntze) (Oliveira-Filho et al., 2015). The riparian 
vegetation of most streams in the region is composed mainly of Campomanesia xanthocarpa (O. Berg), Cupania vernalis (Cambess.), Ocotea puberula (Rich.) Nees, Sebastiania brasiliensis (Spreng.), and Nectandra megapotamica (Spreng.) Mez, among others (OliveiraFilho et al., 2015).

\section{Sampling of vegetative material}

We collected leaves monthly from January to December 2013 in three first-order streams along a distance of approximately $100 \mathrm{~m}$ subdivided at three points (a distance of approximately $30 \mathrm{~m}$ along the 100 $\mathrm{m}$ length) for each stream. We installed 90 collectors $(0.04$ $\mathrm{m}^{2}$ collection area, total area of $3.6 \mathrm{~m}^{2}$ ) suspended about $1 \mathrm{~m}$ from the streambed at each site. We inspected the collectors monthly for 12 months, and the material retained in the collectors was taken to the laboratory and oven-dried $\left(40 \pm 5^{\circ} \mathrm{C}\right.$ for $\left.72 \mathrm{~h}\right)$. Each of the streams was surrounded by different plant formations. The stream with native vegetation $\left(27^{\circ} 32^{\prime} 59^{\prime \prime} \mathrm{S}, 52^{\circ} 07^{\prime} 16^{\prime \prime} \mathrm{W}\right)$ was surrounded by vegetation characteristic of Mixed Ombrophilous Forest; the second stream was surrounded by $P$. elliottii trees $\left(27^{\circ} 36^{\prime} 5^{\prime \prime} \mathrm{S}, 52^{\circ} 11^{\prime} 15^{\prime \prime} \mathrm{W}\right)$, and the third stream was surrounded by E. grandis trees (2736'3”S, 52¹1'14’W).

\section{Leaching experiment}

We transported the leaves in the samplers to the laboratory where they were dried at room temperature for 5 days. After drying, we assembled reactors with $0.5 \pm 0.1$ $\mathrm{g}$ of vegetative material and $50 \mathrm{~mL}$ of sterile water for each forest system (native, E. grandis, and P. elliottii). We placed the reactors in an orbital shaker at $18 \pm 1^{\circ} \mathrm{C}$ at a constant rotation of $80 \mathrm{rpm}$. We defined the temperature and agitation conditions from the physical and chemical characteristics of the streams in the study region (Tonin and Hepp, 2011). However, the reactors with the plant material and the water used for the leaching were closed to avoid contact with the atmospheric air.

After $1 / 4 \mathrm{~h}, 1 \mathrm{~h}, 4 \mathrm{~h}, 12 \mathrm{~h}, 24 \mathrm{~h}$, and $48 \mathrm{~h}$ of incubation, the three reactors of each forest system in the orbital agitator were evaluated for their temporal variations of DIC and DOC leachate. We quantified the concentrations of DIC and DOC using a TOC-VCS-H (Shimadzu $\left.{ }^{\circledR}\right)$ analyser. Prior to the analyses, the samples were filtered through a $0.22-\mu \mathrm{m}$ porosity Millipore ${ }^{\circledR}$ filter to determine the dissolved fractions of carbon.

\section{Data analysis}

We evaluated the concentrations of the DIC and DOC leachate in each forest system for all four seasons of the year using a two-way analysis of variance (two-way ANOVA). The forest systems (three levels) and seasons (four levels) were the categorical factors used in the analysis. We used a posterior Tukey test as a contrast analysis. To evaluate the temporal dynamics ( $48 \mathrm{~h}$ ) of DOC and DIC leaching, we used analysis of covariance (ANCOVA), considering the time of leaching as a covariate. We performed all analyses using $\mathrm{R}$ software ( $\mathrm{R}$ Core Team, 2013).

\section{RESULTS}

After $48 \mathrm{~h}$ of the experiment, we observed that the concentrations of leached DIC and DOC varied among the forest systems. However, this variation was attenuated, depending on the period of the year the leaf litter was obtained (Fig. 1; Tab. 1). The DIC was significantly more
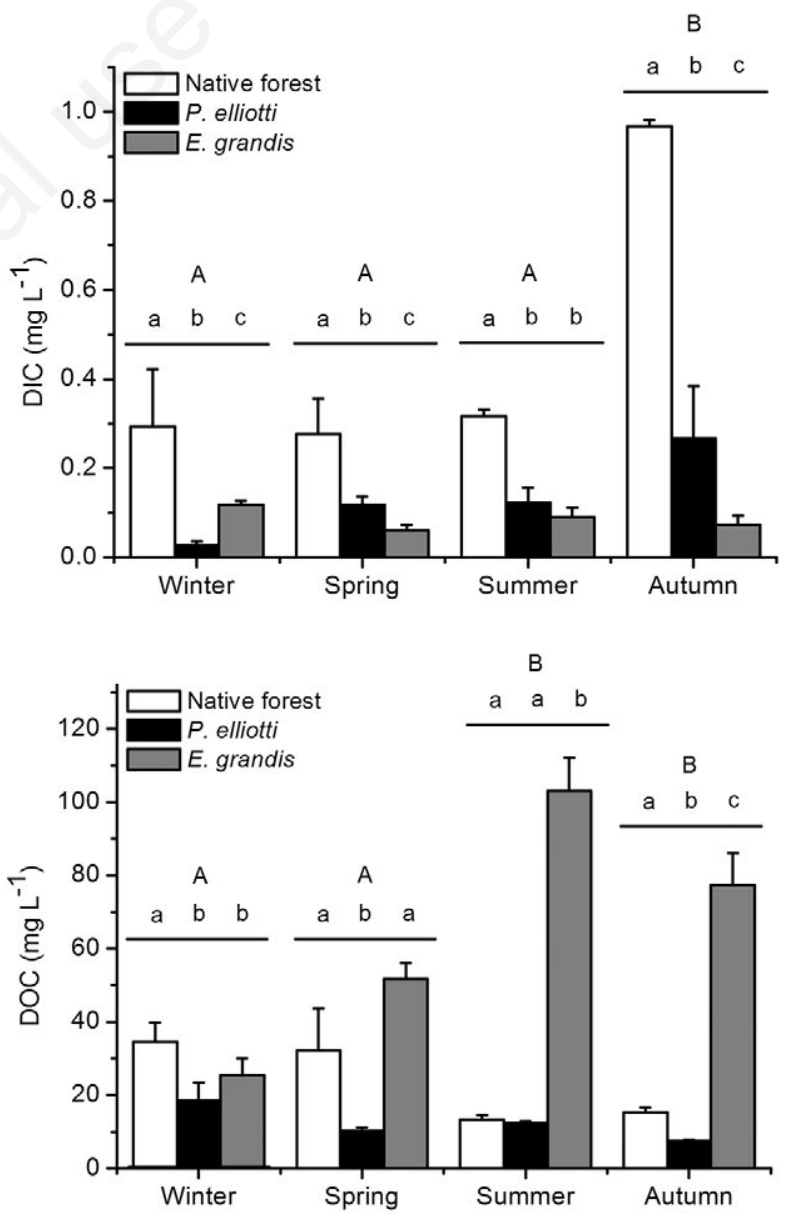

Fig. 1. Mean \pm standard error of the dissolved inorganic carbon (DIC) and dissolved organic carbon (DOC) leaf leaching of native forest and P. elliottii and E. grandis forestry systems in the seasons of the year. Lowercase letters indicate differences (Tukey test, $\mathrm{P}<0.05$ ) among forest systems in the seasons. Capital letters indicate differences among seasons (Tukey test, $\mathrm{P}<0.05$ ). 
leached in the native forest system in the autumn (two way ANOVA, $\mathrm{F}_{(2,24)}=51.5, \mathrm{P}<0.001$; Fig. 1). On the other hand, the concentrations of DIC leached by the forest systems of E. grandis and P. elliottii were similar (Fig. 1). The DOC was significantly leached in greater amounts of $E$. grandis (two way ANOVA, $\mathrm{F}_{(2,24)}=94, \mathrm{P}<0.001$; Fig. 1) in the summer. The DOC leached from the leaf litter from the native and $P$. elliottii systems were similar (Fig. 1).

The leaching dynamics of DIC and DOC in the period of $48 \mathrm{~h}$ of experimentation varied among forest systems depending on the period of the year (Fig. 2). The DIC leaching was increased in the first $12 \mathrm{~h}$ of experiment, and after $24 \mathrm{~h}$, the concentration of leached DIC was decreasing (Fig. 2). The vegetal material of the spring and autumn of native system leached significantly more DIC compared to E. grandis and P. elliottii (ANCOVA; $\mathrm{F}_{(3 ; 50)}=4.5, \mathrm{P}=0.006$ and $\mathrm{F}_{(3 ; 50)}=2.9, \mathrm{P}=0.043$, respectively) (Fig. 2). In the spring, summer and autumn, DOC leached significantly more quantity by $E$. grandis (ANCOVA, $\mathrm{F}_{(3 ; 50)}=28.6$, $\mathrm{P}<0.001 ; \mathrm{F}_{(3 ; 50)}=35.5, \mathrm{P}<0.001 ;$ and $\mathrm{F}_{(3 ; 50)}=21.8, \mathrm{P}<0.001$, respectively) (Fig. 3). The DOC leaching showed an increasing pattern throughout the $48 \mathrm{~h}$ of the experiment.

\section{DISCUSSION}

Our study demonstrated that the composition of riparian vegetation is important to dynamics of carbon in aquatic environments. As small-order streams are dependent of the allochthonous sources to maintain their energy demands, the input organic matter is critical to sustaining aquatic communities. The native litter contributed with the highest concentrations of DIC, while the litter of E. grandis contributed DOC. As the variation of DIC and DOC leached by the different leaf litter (i.e., native and non-native) varied significantly, our results highlight the importance of carbon leaching to aquatic environments, contributing to the understanding of the ecological processes in the aquatic cycling of nutrients.
Our results demonstrated that the replacement of native species in riparian zones by non-native forest monocultures could alter the chemical composition of the water. The litter is an important source of carbon for streams as it is rapidly leached when it comes into contact with stream water (Fröberg et al., 2005). In addition, the variation of the carbon composition of the plants depended on the annual periodicity, since variations in the concentrations of the DIC and DOC leachate were observed in the different seasons. Some phytophysiological characteristics of the species studied explain these variations. The native forest is composed of a high variety of plant species, especially in the region studied. According to Duan et al. (2014) the variety and amount of litter entering the aquatic environment contributes to the chemical composition of the water, especially to dissolved carbon and nitrogen. The study area includes a transition zone of the Atlantic Forest, where there are species characteristic of both Mixed and Semideciduous Ombrophilous Forest (Oliveira-Filho et al., 2015). This feature causes the forest remnants observed in the Upper Uruguay region to be composed of species with very broad phenological variability. Thus, it is expected that the organic matter input of these species to streams will vary throughout the year (Capellesso et al., 2016); consequently, the streams will vary chemically (Tonin et al., 2014).

The presence of DOC in streams is important for the nutrient dynamics of these environments, supporting metabolism and aquatic functioning (Stanley et al., 2012). The concentration of DOC in streams is related to the surrounding landscape, especially the vegetation that composes the riparian zone (Laudon et al., 2011). We observed high DOC concentrations leached from $E$. grandis detritus. As this species has leaves with large amounts of hydrosoluble compounds, the presence of debris of this species is an important source of COD for aquatic environments. According to Wymore et al. (2018) leaves with high concentrations of tannins and lignins (e.g., E. grandis) may contribute decisively to greater

Tab.1. Results of the two-way ANOVA to dissolved inorganic carbon and dissolved organic carbon leaf leaching of native forest and non-native $P$. elliottii and $E$. grandis forestry systems.

\begin{tabular}{|c|c|c|c|c|c|}
\hline & df & SS & MS & $\mathbf{F}$ & P-value \\
\hline \multicolumn{6}{|l|}{ Dissolved inorganic carbon } \\
\hline Forest system & 2 & 1.01 & 0.51 & 51.5 & $<0.001$ \\
\hline Seasons & 3 & 0.52 & 0.17 & 17.7 & $<0.001$ \\
\hline Forest system: seasons & 6 & 0.58 & 0.09 & 9.8 & $<0.001$ \\
\hline Residuals & 24 & 0.23 & 0.01 & & \\
\hline \multicolumn{6}{|l|}{ Dissolved organic carbon } \\
\hline Forest system & 2 & 18061 & 9030 & 94.0 & $<0.001$ \\
\hline Seasons & 3 & 1321 & 440 & 4.6 & 0.011 \\
\hline Forest system: seasons & 6 & 10013 & 1669 & 1.4 & $<0.001$ \\
\hline Residuals & 24 & 2305 & 96 & & \\
\hline
\end{tabular}


release of DOC to the aquatic system. The slower DOC leaching observed for $P$. elliottii is associated with the amount of resins and lignin in the needles that occurs in this species. These results corroborate those of Huang et al. (2013), who observed similar patterns of DOC released from Pinus spp.

The native forest system contributed the highest amount of DIC leachate. According to Öquist et al. (2005) the amount of DIC in the streams is dependent of the riparian vegetation. In diverse riparian systems (e.g. native trees composition), the leaves are usually more malleable and thinner, with lower concentrations of structural nutrients in relation to those of the non-native species (Tonin et al., 2014). In addition, the leaching of DIC occurred in the first $12 \mathrm{~h}$, suggesting that there was greater dissolution of soluble inorganic substances in the initial period of the experiment. The DIC is an important component for the carbon balance in streams because $\mathrm{CO}_{2}$ production is often insignificant in lotic systems (Öquist et al., 2005). In this way, the input of allochthonous organic matter sources as a subsidy of DIC to the systems is fundamental for carbon balance. The ionic bonds of inorganic compounds are more susceptible to interactions with water, contributing to their faster release than organic compounds (Canhoto and Laranjeira, 2007). The mineralization of organic matter depends on physical (e.g. leaching) and biological (e.g., microorganisms and shredders) action (Albariño and Balseiro, 2002). Thus, the input of diversified litter plants into the stream facilitates the complete mineralization of organic matter $\left(\mathrm{CO}_{2}\right.$ production), since these litters can present varying amounts of organic and inorganic compounds which facilitate the action of decomposing organisms. The litter production of $P$. elliottii and E. grandis is constant
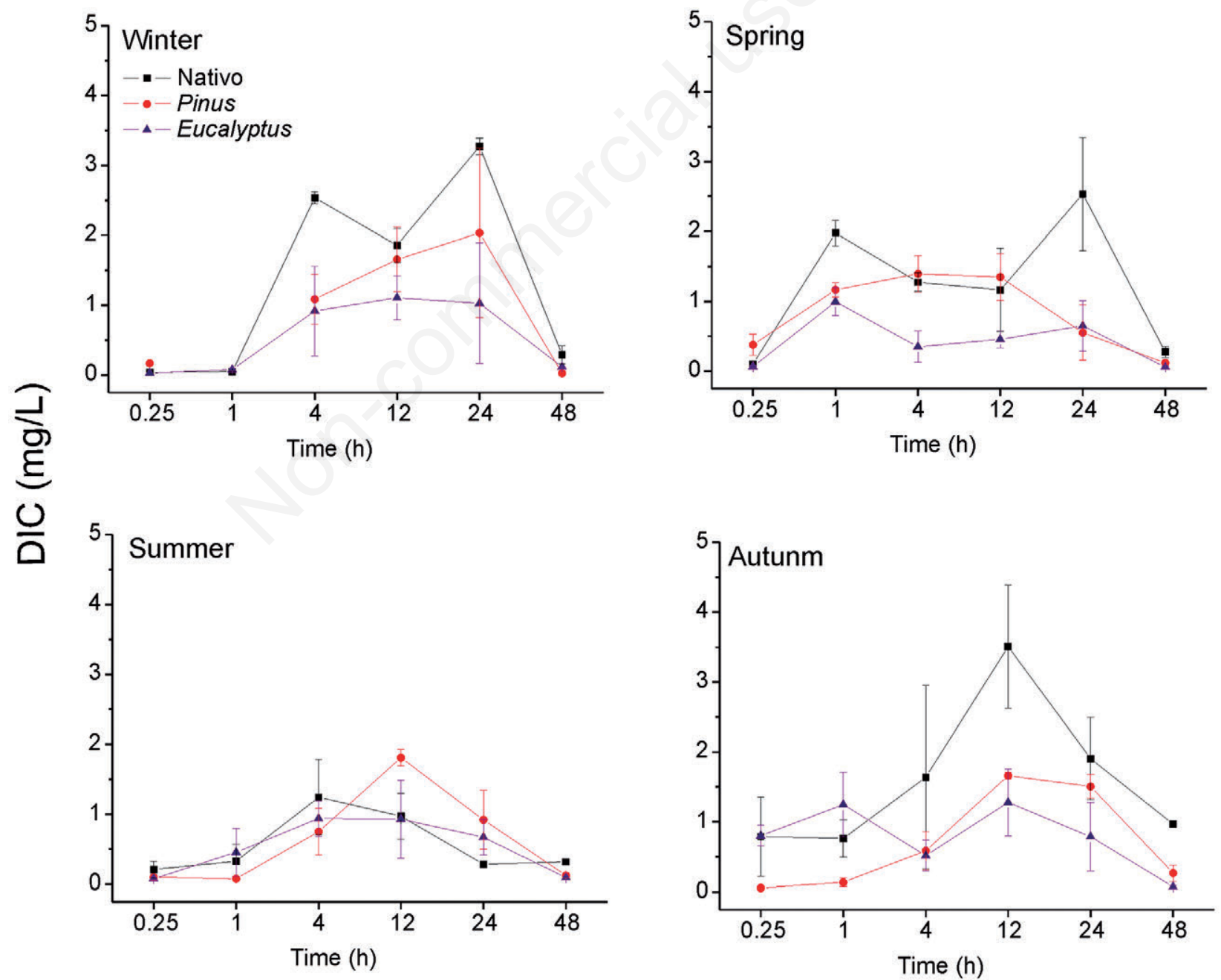

Fig. 2. Dynamic of the leaching of dissolved inorganic carbon (DIC) in native forest and P. elliottii and E. grandis forestry systems in the seasons of the year. The points represent the mean values and the bars represent the standard error. 
throughout the year due to their phenological characteristics. Thus, with a constant input of organic matter into the streams, the chemical composition of the water may be subject to significant modifications. Litter from P. elliottii and E. grandis contains large amounts of phenolic compounds, organic acids, and other substances that exert negative effects on microrganisms and aquatic biota (Hepp et al., 2009). Considering that many other substances are leached from plant debris, not just DIC and DOC, the negative effects of non-native litter plant on ecological functioning and integrity may be significant (Albariño and Balseiro, 2002). Even though the contribution in terms of carbon sequestration by nonnative species is high, the damage caused by these species is significant and should be considered (Hepp and Gonçalves, 2015).

A recent meta-analysis demonstrated the negative

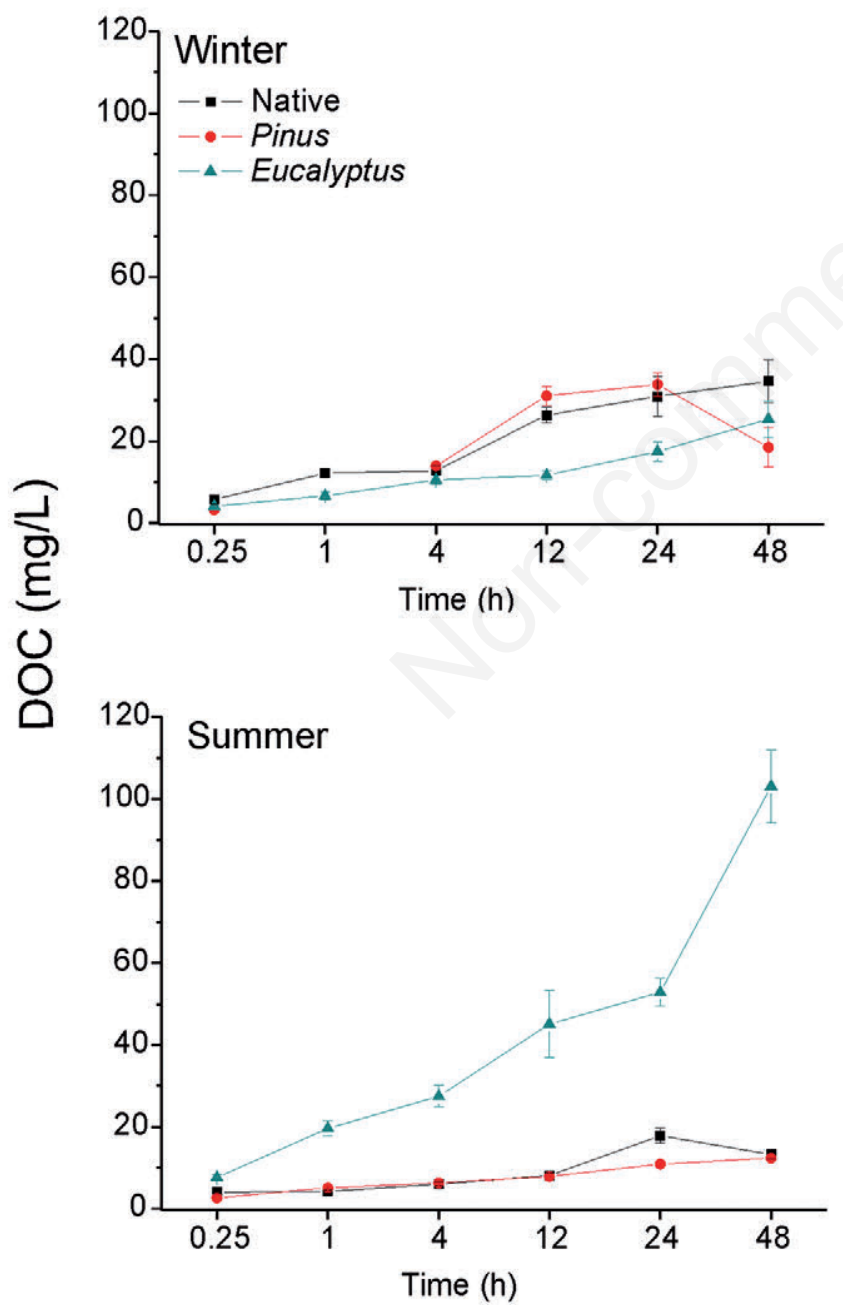

effects of replacing native forests with monocultures on the ecological processes in streams (Ferreira et al., 2016). In this study, the authors noted that Eucalyptus spp. causes serious damage to the processing of organic matter in streams. In addition, E. grandis plantations reduced about $45 \%$ of the aquatic invertebrate biodiversity in the streams, while P. elliottii plantations reduced about $75 \%$ of the biodiversity of these organisms. If we consider that aquatic invertebrates are links in the aquatic trophic chains, variations in higher levels of these food chains can be expected.

\section{CONCLUSIONS}

Our study considered only one stage of the decomposition process (leaching). The leaching of soluble
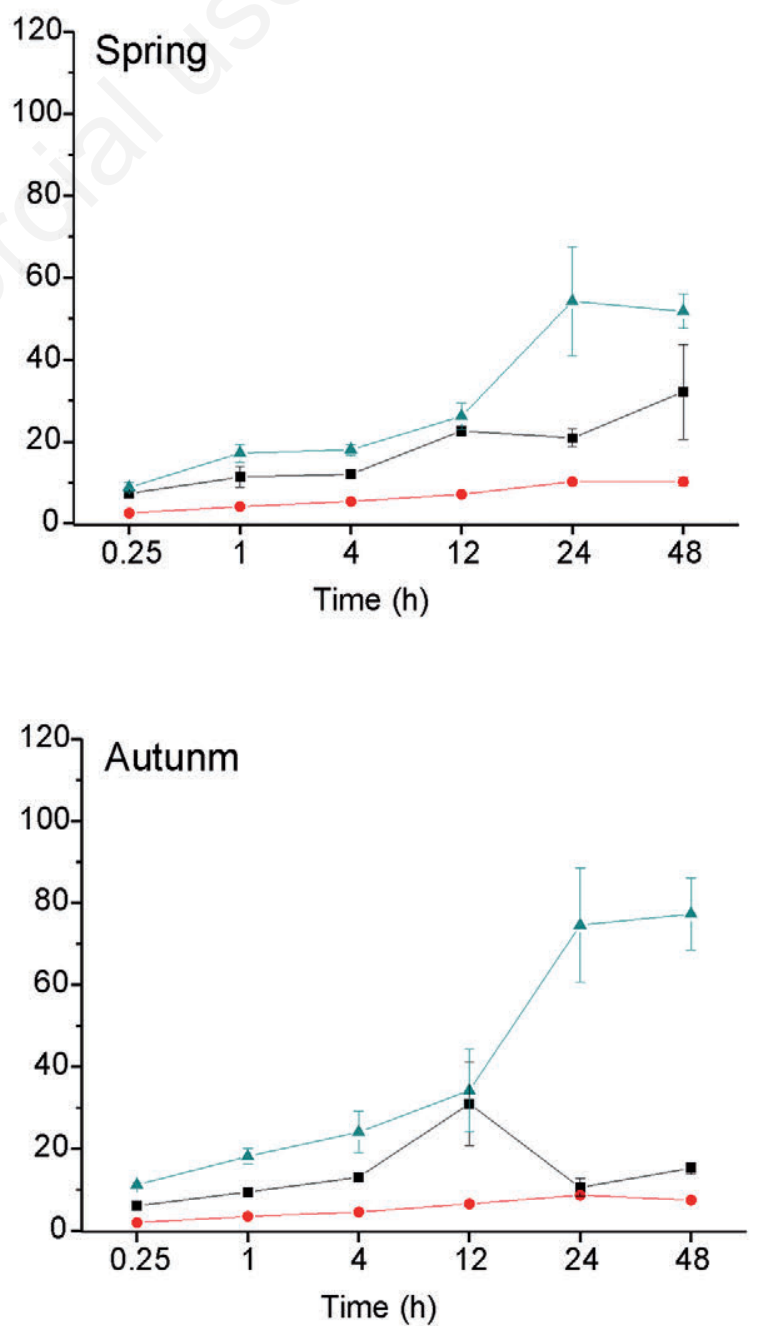

Fig. 3. Dynamic of the leaching of dissolved organic carbon (DOC) in native forest and P. elliottii and E. grandis forestry systems in the seasons of the year. The points represent the mean values and the bars represent the standard error. 
compounds is the first step in the process of decomposition of allochthonous organic matter in streams. This step is important for the release of soluble compounds (e.g., phenols), which may influence microbial colonization and subsequent fragmentation. In addition, the dissolved fractions of carbon are fundamental for the direct incorporation by aquatic plants and microorganisms. In addition, the results presented in this paper reinforce the need for a more careful look at ecological processes. Integrated ecosystem assessment, considering both the structural and functional aspects, as well as physical, chemical, and biological factors would lead to a more complete assessment of the actual environmental conditions of habitats.

\section{ACKNOWLEDGMENTS}

We thank the Irineu J. Preczewski for contribution into laboratorial analysis. We thank Rafael Loureiro and Lucas Fontana for their contributions in the field work. We would like to thank the two anonymous reviewers for the important suggestions in a preliminary version this manuscript that have promoted significant improvement in text quality. The work was financed by the Support Program for Technological Innovation Poles of the State of Rio Grande do Sul (Secretariat of Science and Technology of the Rio Grande do Sul state).

\section{REFERENCES}

Albariño RJ, Balseiro RG, 2002. Leaf litter breakdown in Patagonian streams: native versus exotic trees and the effect of invertebrate size. Aquat. Conserv. 12:181-192.

Allan, JD, Castillo, MM, 2007. Stream ecology: structure and function of running waters: Chapmen \& Hall, London: 436 pp.

Alvares CA, Stape JL, Sentelhas PC, Moraes G, Leonardo J, Sparovek G, 2013. Köppen's climate classification map for Brazil. Meteorol. Z. 22:711-728.

Bambi P, Rezende RS, Feio MJ, Marques, GF, Alvin E, Quintão JMB, Araujo F, Gonçalves JF, 2017. Temporal and Spatial Patterns in Inputs and Stock of Organic Matter in Savannah Streams of Central Brazil. Ecosystems 20:757-768.

Bärlocher F, 2005. Leaching, p. 33-36. In: M.A.S. Graça, F. Bärlocher and M.O. Gessner (eds.), Methods to study litter decomposition: A practical guide. Springer, Dordrecht.

Buonocore E, Häyhä T, Paletto A, Franzese PP, 2014. Assessing environmental costs and impacts of forestry activities: a multi-method approach to environmental accounting. Ecol. Model. 271:10-20.

Canhoto C, Laranjeira C, 2007. Leachates of Eucalyptus globulus in intermittent Streams Affect Water Parameters and Invertebrates. Hydrobiologia 92:173-182.

Capellesso ES, Scrovonski KL, Zanin EM, Hepp LU, Bayer C, Sausen TL, 2016. Effects of forest structure on litter production, soil chemical composition and litter soil interactions. Acta Bot. Bras. 30:329-335.
Cole JJ, Caraco NF, Kling JW, Kratz TK, 1994. Carbon dioxide supersaturation in the surface waters of lakes. Science 265:1568-1570.

Corral-Fernández R, Parras-Alcántara L, Lozano-García B, 2013. Stratification ratio of soil organic $C, N$ and $C: N$ in Mediterranean evergreen oak woodland with convectional and organic tillage. Agr. Ecosyst. Environ. 164:252-259.

Cunha-Santino MB, Pacobahyba LD, Bianchini JI, 2003. Changes in the amount of soluble carbohydrates and polyphenols contents during decomposition of Montrichardia arborescens (L.) Schott. Acta Amazônica 33:469-476.

Dahm CN, 1981. Pathways and mechanisms for removal of dissolved organic carbon from leaf leachate in streams. Can. J. Fish. Aquat. Sci. 38:68-76.

Duan S, Delaney-Newcomb K, Kaushal SS, Findlay SEG, Belt KT, 2014. Potential effects of leaf litter on water quality in urban watersheds. Biogeochemistry 121:61-80.

Ferreira V, Raposeiro PM, Pereira A, Cruz A, Costa AC, Graça MAS, Gonçalves V, 2016. Leaf litter decomposition in remote oceanic islands streams is driven by microbes and depends on litter quality and environmental conditions. Freshwater Biol. 61:783-799.

Finlay JC, 2003. Controls of streamwater dissolved inorganic carbon dynamics in a forested watershed. Biogeochemistry 62:231-252.

Fröberg M, Kleja DB, Bergkvist BO, Tipping E, Mulder J. 2005. Dissolved organic carbon leaching from a coniferous forest floor - a field manipulation experiment. Biogeochemistry 75:271-287.

Giling DP, Grace MR, Thomson JR, Nally RM, Tompson RM, 2014. Effect of native vegetation loss on stream ecosystem processes: dissolved organic matter composition and export in agricultural landscapes. Ecosystems 17:82-95.

Gonçalves JF, Callisto M, 2013. Organic-matter dynamics in the riparian zone of a tropical headwater stream in Southern Brazil. Aquat. Bot. 109:8-13.

Graça MAS, 2001. The role of invertebrates on leaf decomposition in streams: a review. Int. Rev. Hydrob. 86:383-393.

Hepp LU, Delanora R, Trevisan A, 2009. [Compostos secundários durante a decomposição foliar de espécies arbóreas em um riacho do sul do Brasil].[Article in Portuguese]. Acta Bot. Bras. 23:407-413.

Hepp LU, Gonçalves JF, 2015. [A decomposição de detritos em riachos como serviço ecossistêmico de regulação e suporte prestado pela natureza], p. 226-233. In: L.M. Parron, J.R. Garcia, E.B. Oliveira, G.G. Brown, R.B. Prado (eds.), [Serviços ambientais em sistemas agrícolas e florestais do bioma Mata Atlântica].[Book in Portuguese]. Editora Embrapa, Brasília.

Hillman GR, Feng JC, Feng CC, Wang Y, 2004. Effects of catchment characteristics and disturbances on storage and export of dissolved organic carbon in a boreal headwater stream. Can. J. Fish. Aquat. Sci. 61: 1447-1460.

Huang W, Mcdowell WH, Zou X, Ruan H, Wang J, LI L, 2013. Dissolved organic carbon in headwater streams and riparian soil organic carbon along an altitudinal gradient in the Wuyi Mountains, China. Plos One 8:e78973.

Kominoski JS, Rosemond AD, 2012. Conservation from the 
bottom up: forecasting effects of global change on dynamics of organic matter and management needs for river networks. Freshwater Sci. 31:51-68.

Lamberti GA, Gregory SV, 2007. CPOM transport, retention, and measurement, p. 273-289. In: F.R. Hauer and G.A. Lamberti (eds.), Methods in stream ecology. Elsevier, San Diego.

Lennon JT, Pfaff LE, 2005. Source and supply of terrestrial organic matter affect aquatic microbial metabolism. Aquat. Microb. Ecol. 39:107-119.

Laudon H, Berggren M, Agren A, Buffam I, Bishop K, Grabs T, Jansson M, Köhler S, 2011. Patterns and dynamics of dissolved organic carbon (DOC) in boreal streams: The role of processes, connectivity, and scaling. Ecosystems 14:880893.

Mcknight DM, Aiken GR, 1998. Sources and age of aquatic humus, p. 9-39. In: D.O. Hessen and L.J. Tranvik (eds.), Ecological studies: Aquatic humic substances. SpringerVerlag, Berlin.

Moorhead DL, Sinsabaugh RL, Likins AE, Reynolds JF, 1996. Decomposition processes: modeling approaches and applications. Sci. Total Environ. 183:137-149.

Naimann RJ, Décamps H, 1990. The ecology and management of aquatic-terrestrial ecotones. Parthenon, Paris: 316 pp.

Oliveira EB, 2015. [Plantações florestais: Geração de benefícios com baixo impacto ambiental].[Book in Portuguese]. Embrapa Florestas, Colombo: 87 pp.

Oliveira-Filho A, Budke JC, Jarenkow JA, Eisenlohr PV, Neves DRM, 2015. Deving into the variations in tree species composition and richness across South American subtropical Atlantic and Pampean forest. J. Plant Ecol.-UK 8:242-260.

Ơquist MG, Wallin M, Seibert J, Bishop K, Laudon H, 2005. Dissolved inorganic carbon export across the soil/stream interface and its fate in a boreal headwater stream. Environ. Sci. Technol. 43:7364-7369.

Polunin NVC, 1984. The decomposition of emergent macrophyte in freshwater. Adv. Ecol. Res. 14:115-166.

R Core Team, 2015. R: A language and environment for statistical computing. R Foundation for Statistical Computing, Vienna, Austria.

Rezende AV, Vale AT, Sanquetta CR, Filho AF, Felfili JM, 2008. Comparison of mathematical models to volume, biomass and carbon stock estimation of the woody vegetation of a Cerrado Sensu Stricto in Brasilia, DF. Sci. For. 71:65-76.

Richardson JJ, Sato T, 2015. Resource subsidy flows across freshwater-terrestrial boundaries and influence on processes linking adjacent ecosystems. Ecohydrology 8:406-415.

Schulz R, Bundschuh M, Gergs R, Brühl CA, Diehl D, Entling MH, Fahse L, Frör O, Jungkunst HF, Lorke A, Schäfer RB, Schumann GE, Schwenk K, 2015. Review on environmental alterations propagating from aquatic to terrestrial ecosystems. Sci. Total Environ. 538:246-261.

Stanley EH, Powers SM, Lottig NR, Buffam I, Crawford JT, 2012. Contemporary changes in dissolved organic carbon (DOC) in human dominated rivers: is there a role for DOC management? Freshwater Biol. 57:26-42.

Strak D, 1997. Phenolic metabolism, p. 205-236. In: P.M. Dey and J.B. Harborne (eds.), Plant biochemistry. Academic Press, San Diego.

Tonin AM, Hepp LU, 2011. Effects of nitrate enrichment on leaf litter decomposition. Acta Limnol. Bras. 23:86-94.

Tonin AM, Restello RM, Hepp LU, 2014. Chemical change of leaves during breakdown affects associated invertebrates in a subtropical stream. Acta Limnol. Bras. 26:235-244.

Tonin AM, Gonçalves Jr JF, Bambi P, Couceiro SRM, Feitoza LAM, Fontana LE, Hamada N, Hepp LU, Lezan-Kowalczuk VG, Leite GFM, Lemes-Silva AL, Lisboa LK, Loureiro RC, Martins RT, Medeiros AO, Morais PB, Moretto Y, Oliveria PCA, Pereira EB, Ferreira LP, Pérez J, Petrucio MM, Reis DF, Rezende RS, Roque N, Santos LEP, Siegloch AE, Tonello G, Boyero L, 2017. Plant litter dynamics in the forest-stream interface: precipitation is a major control across tropical biomes. Sci. Rep. 7:10799.

Vannote RL, Minshall GW, Cummins KW, Sedell JR, Cushing CE, 1980. The river continuum concept. Can. J. Fish. Aquat. Sci. 37:130-137.

Wetzel RG, 1995. Death, detritus and energy flow in aquatic ecosystems. Freshwater Biol. 33:83-89.

Wallace JB, Eggert SL, Meyer JL, Webster JR, 1997. Multiple trophic levels of a forest stream linked to terrestrial litter inputs. Science 277:102-104.

Wilson HF, Xenopoulos MA, 2008. Ecosystem and seasonal control of stream dissolved organic carbon along a gradient of land use. Ecosystems 11:555-568.

Wymore AS, Salpas E, Casaburi G, Liu CM, Price LB, Hungate BA, McDowell WH, Marks JC, 2018. Effects of plant species on stream bacterial communities via leachate from leaf litter. Hydrobiologia 807:131-144.

Yamashita Y, Kloeppel BD, Knoepp J, Zausen GL, Jaffé R, 2011. Effects of watershed history on dissolved organic matter characteristics in headwater streams. Ecosystems 14:1110-1122. 